\title{
SISTEM INFORMASI PENGELOLAAN ADMINISTRASI ORGANISASI KEMAHASISWAAN DI STMIK STIKOM INDONESIA
}

\author{
Dewa Putu Yudhi Ardiana ${ }^{1)}$ I Wayan Dharma Suryawan ${ }^{2)}$ Eddy Hartono $^{3)}$ \\ Program Studi Teknik Informatika 1) 2) 3) \\ STMIK STIKOM Indonesia, Denpasar, Bali ${ }^{1) 2) 3)}$ \\ dewa.yudhi@gmail.com ${ }^{1)}$ dharma.suryawan@gmail.com ${ }^{2)}$ \\ eddy_h99@yahoo.com ${ }^{3)}$
}

\begin{abstract}
Student organizations (ORMAWA) are a place for students to develop interests, talents, skills and social abilities. Research shows that ORMAWA provides benefits for students such as training leadership, time management, networking, social skills, problem-solving and conflict management and being able to increase learning motivation. STMIK STIKOM Indonesia views ORMAWA had an important role in student personal development. Currently, STMIK STIKOM Indonesia had 32 ORMAWA who obliged to guided and supervised. STMIK STIKOM Indonesia has difficulties in knowing the conditions and assessing ORMAWA because administrative management is still manual. The system for managing the administration of student organizations is needed to help institutions guide student organizations. This system will provide information about the condition of ORMAWA. The assessment of the condition of ORMAWA based on member activeness, number of activities, number of participants and discipline on administration. The assessment is done using the Simple Additive Weighting (SAW) method. The results of this study indicate that it has successfully developed an information system for student administration management. Information systems can generate information on activeness of ORMAWA, ORMAWA activities and ORMAWA condition reports with SAW calculations. The saw method is not suitable to be used in determining the conditions of the people. This because the assessment is carried out relative to other ORMAWA conditions. This relative assessment can produce different assessments of the same conditions. Keywords: Simple Additive Weighting, assessment using multi criteria, student organizations, administrative management, information systems
\end{abstract}

\begin{abstract}
ABSTRAK
Organisasi kemahasiswaan (ORMAWA) merupakan wadah mahasiswa untuk mengembangkan minat, bakat, keahlian dan kemampuan sosial. Penelitian menunjukkan bahwa ORMAWA memberikan manfaat bagi mahasiswa seperti melatih leadership, belajar mengatur waktu, memperluas jaringan, mengasah kemampuan sosial, problem solving dan manajemen konflik serta mampu meningkatkan motivasi belajar mahasiswa. STMIK STIKOM Indonesia memandang organisasi kemahasiswaan memiliki peran yang sangat penting bagi pengembangan diri mahasiswa. STMIK STIKOM Indonesia saat ini memiliki 32 ORMAWA yang wajib dibina dan diawasi. Pengelolalan administrasi kemahasiswaan saat ini dilakukan secara manual sehingga menyulitkan institusi untuk mengetahui kondisi dan memberikan penilaian terhadap kondisi ORMAWA. Sistem untuk mengelola administrasi organisasi kemahasiswaan diperlukan untuk membantu institusi melakukan pengawasan dan pembinaan terhadap organisasi kemahasiswaan. Sistem ini akan memberikan informasi mengenai kondisi organisasi kemahasiswaan. Penilaian kondisi organisasi kemahasiswaan didasarkan pada keaktifan anggota organisasi kemahasiswaan, jumlah kegiatan, partisipasi mahasiswa dalam kegiatan kemahasiswaan, dan kedisiplinan organisasi kemahasiswaan dalam hal administrasi. Penilaiannya dilakukan dengan menggunakan metode Simple Additive Weighting (SAW).
\end{abstract}


Hasil penelitian ini menunjukkan telah berhasil mengembangkan sistem informasi pengelolaan administrasi kemahasiswaan. Sistem informasi yang dikembangkan dapat menghasilkan informasi keaktifan ORMAWA, kegiatan ORMAWA dan laporan kondisi ORMAWA dengan perhitungan SAW. Metode SAW belum tepat digunakan dalam penentuan kondisi ORMAWA. Hal ini disebabkan karena penilaian dilakukan secara relatif terhadap kondisi ormawa yang lain. Penilaian secara relatif ini dapat menghasilkan penilaian yang berbeda terhadap kondisi yang sama.

Kata Kunci: Simple Additive Weighting, penilaian menggunakan multi kriteria, organisasi kemahasiswaan, pengelolaan administrasi, sistem informasi

\section{PENDAHULUAN}

Organisasi kemahasiswaan (ormawa) merupakan wadah mahasiswa untuk mengembangkan minat, bakat, keahlian dan kemampuan sosial. Ormawa memberikan manfaat yang besar bagi mahasiswa. Manfaat keterlibatan mahasiswa dalam ormawa dikemukakan dalam Pertiwi dkk. (2015) dan Pratiwi (2017). Pertiwi dkk. (2015) menyatakan bahwa manfaat yang dapat dirasakan oleh mahasiswa dengan terlibat dalam organisasi mahasiswa antara lain melatih leadership, belajar mengatur waktu, memperluas jaringan, mengasah kemampuan sosial, problem solving dan manajemen konflik. Menurut Pratiwi (2017), semakin tinggi keaktifan mahasiswa dalam organisasi maka akan semakin tinggi pula prestasi belajar mahasiswa tersebut. Hal ini mematikan stigma yang mengatakan keaktifan organisasi hanya akan menggangu waktu belajar dan membuat prestasi belajar menurun.

STMIK STIKOM Indonesia, sebagai salah satu penyelenggara pendidikan tinggi, memandang organisasi kemahasiswaan memiliki peran yang sangat penting bagi pengembangan diri mahasiswa. Dukungan serta pembinaan organisasi kemahasiswaan terus diupayakan untuk mendorong mahasiswa terlibat aktif dalam organisasi kemahasiswaan. Dari delapan organisasi kemahasiswaan pada tahun 2014, jumlah organisasi kemahasiswaan di STMIK STIKOM Indonesia meningkat menjadi 21 pada tahun 2015. Kini STMIK STIKOM Indonesia memiliki 26 organisasi kemahasiswaan.

Pengembangan diri mahasiswa dilakukan melalui kegiatan kemahasiswaan. Kegiatan kemahasiswaan adalah kegiatan yang dilaksanakan oleh organisasi kemahasiswaan dan diakui oleh institusi STMIK STIKOM Indonesia. Agar dapat diakui oleh institusi, kegiatan yang hendak dilaksanakan oleh organisasi kemahasiswaan harus mendapatkan persetujuan institusi, yang diwakili oleh pembina organisasi kemahasiswaan, bagian kemahasiswaan, dan pembantu ketua III. Organisasi kemahasiswaan harus menyerahkan laporan pertanggungjawaban untuk setiap kegiatan kemahasiswaan yang telah dilaksanakan.

Pengelolaan ormawa di STMIK STIKOM Indonesia selama ini dilakukan secara manual. Pengelolaan secara manual ini mengakibatkan institusi mengalami kesulitan untuk mengetahui kondisi ormawa. Kondisi ormawa meliputi keaktifan anggota organisasi kemahasiswaan, jumlah kegiatan, partisipasi mahasiswa dalam kegiatan kemahasiswaan, dan kedisiplinan organisasi kemahasiswaan dalam hal administrasi. Ketidakmampuan institusi dalam mengetahui kondisi ormawa mengakibatkan proses pembinaan tidak dapat berjalan sebagaimana mestinya.

Untuk dapat melaksanakan pembinaan secara optimal, institusi memerlukan informasi mengenai kondisi ormawa. Pengelolaan secara manual tidak memungkinkan institusi untuk mendapatkan informasi mengenai kondisi ormawa dengan akurat, cepat, dan mudah. Untuk itu, diperlukan sistem terkomputerisasi untuk mendapatkan informasi kondisi. Sistem ini nantinya dapat memberikan informasi kegiatan kemahasiswaan yang telah terlaksana, partisipasi mahasiswa dalam kegiatan kemahasiswaan, laporan pertanggungjawaban. Sistem juga dapat memberikan penilaian kondisi organisasi kemahasiswaan, yang didasarkan pada beberapa kriteria yaitu keaktifan anggota organisasi kemahasiswaan, jumlah kegiatan, partisipasi mahasiswa dalam kegiatan kemahasiswaan, dan kedisiplinan organisasi kemahasiswaan dalam hal administrasi.

\section{TINJAUAN PUSTAKA}

Organisasi kemahasiswaan memiliki peranan yang sangat penting bagi mahasiswa, namun pengelolaannya menjadi sulit ketika dilakukan secara manual. Sistem pengelolaan organisasi kemahasiswaan diperlukan untuk mempermudah pengelolaan organisasi kemahasiswaan. 
Penelitian-penelitian yang membahas mengenai pengelolaan organisasi kemaha-siswaan telah dilaksanakan. Penelitian-penelitian tersebut diantaranya Devirgieni dkk. (2015), Asri dkk. (2016), serta Sadewa dan Siahaan (2016). Selain itu terdapat juga penelitian Mulyani (2016) yang membahas mengenai pengelolaan sistem kredit partisipasi mahasiswa.

Devirgieni dkk. (2015) membahas tentang pengembangan sistem informasi manajemen Unit Kegiatan Mahasiswa (UKM) Tari Tradisional di STMIK STIKOM Bali. Sistem yang dikembangkan dalam penelitian ini dapat memberikan informasi tentang UKM PRAGINA seperti event yang sudah terlaksana, pengurus UKM dari tahun ke tahun, anggotaanggota yang sudah terdaftar beserta data pribadinya, dokumentasi event. Sistem juga dapat menyampaikan pesan penting kepada anggota UKM melalui layanan Short Message Service (SMS).

Asri dkk. (2016) membahas tentang pengembangan sistem informasi untuk mengelola kegiatan Unit Kegiatan Mahasiswa (UKM) di lingkungan Politeknik Negeri Bali. Sistem yang dihasilkan dalam penelitian ini adalah sebuah sistem informasi berbasis web. Sistem yang dihasilkan dalam penelitian ini mampu menangani pendaftaran anggota Unit Kegiatan Mahasiswa, pembuatan kode absen daring dan mengecek serta mengunduh absensi kegiatan UKM, serta menampilkan informasi mengenai kegiatan Unit Kegiatan Mahasiswa.

Sadewa dan Siahaan (2016) melakukan analisis dan perancangan sebiah sistem informasi untuk mengelola Unit Kegitan Mahasiswa (UKM). Penelitian ini menghasilkan sebuah prototipe sistem informasi berbasis web yang dapat memberikan informasi mengenai kegiatan UKM, informasi mengenai anggota dan pengurus UKM, informasi berupa laporan rekap kegiatan dan dana kegiatan. Sistem yang dikembangkan juga mampu menangani pendaftaran anggota UKM dan memungkinkan terjadinya interaksi antara admin, anggota, dan pengunjung situs melalui kritik dan saran.

Mulyani (2016) tidak membahas mengenai pengelolaan organisasi kemahasiswaan secara langsung. Meskipun tidak berkaitan langsung, penelitian ini masih terkait dengan organisasi kemahasiswaan. Mulyani (2016) membahas mengenai pengelolaan sistem kredit partisipasi aktivitas mahasiswa pada Fakultas Sains dan Teknologi Universitas Respati Yogyakarta (FST UNRIYO). Sistem kredit partisipasi aktivitas ini muncul setelah mahasiswa mengikuti kegiatan ektrakurikuler dan non kurikuler yang dilaksanakan oleh FST
UNRIYO. Sistem yang dihasilkan dalam penelitian ini menyediakan fitur pengelolaan data institusi yang meliputi data fakultas, program studi, dan pengelolaan data mahasiswa, fitur pengelolaan data bidang kegiatan yang meliputi: bidang utama, spesifikasi bidang kegiatan, tipe bidang kegiatan dan ruang lingkup bidang kegiatan, fitur input bobot SKP, dan fitur pengelolaan data mahasiswa.

Penelitian yang berhubungan dengan pengelolaan organisasi mahasiswa umumnya dikembangkan dengan menitikberatkan pada mahasiswa serta organisasi kemahasiswaan. Penelitian ini memiliki perbedaan dengan penelitian-penelitian yang telah disebutkan diatas, yaitu penelitian ini lebih menitikberatkan pada institusi. Sistem yang dikembangkan pada penelitian ini diharapkan dapat membantu institusi untuk melakukan pengawasan dan pembinaan terhadap organisasi kemahasiswaan. Sistem yang dihasilkan dalam penelitian ini diharapkan dapat membantu institusi untuk melakukan pengawasan dan pembinaan. Fitur yang dimiliki oleh sistem untuk membantu institusi melakukan pengawasan dan pembinaan organisasi kemahasiswaan adalah memberikan penilaian terhadap kondisi organisasi kemahasiswaan. Penilaian dilakukan dengan memperhitungkan beberapa kriteria seperti tingkat keaktifan anggota organisasi kemahasiswaan, jumlah dan level kegiatan yang dilaksanakan oleh organisasi kemahasiswaan, tingkat partisipasi mahasiswa dalam kegiatan kemahasiswaan, dan tingkat kedisiplinan organisasi kemahasiswaan dalam hal administrasi.

Penelitian yang membahas mengenai pemberian nilai dengan memperhitungkan beberapa kriteria telah dilaksanakan. Penelitianpenelitian tersebut antara lain Gea (2016) serta Harjanti dan Rozi (2016).

Gea (2016) membuat analisa kinerja Pegawai dengan menggunakan model Fuzzy Multiple Attribute Decision Making (FMADM). Metode yang digunakan adalah Simple Additive Weighting (SAW). Penilaian dilakukan dengan memperhitungkan golongan, masa kerja, latihan jabatan, pendidikan, dan hasil akhir Daftar Penilaian Pelaksanakan Pekerjaan (DP3). Hasil dari penilaian ini digunakan sebagai pertimbangan untuk memilih pegawai yang akan mendapatkan promosi jabatan.

Harjanti dan Rozi (2016) mengembangkan sebuah sistem informasi penilaian supplier komputer dengan menggunakan metode Fuzzy Multiple Attribute Decision Making (FMADM) dengan Simple Additive Weighting (SAW). Penelitian ini menggunakan sembilan kriteria 
untuk menentukan penilaian terhadap supplier komputer, yaitu kriteria harga, waktu pengiriman, kualitas bahan, kondisi packaging, ketersediaan stock, pelayanan, administrasi tagihan, tempo pembayaran, dan kesesuaian PO dengan barang yang datang. Hasil dari penilaian ini digunakan sebagai pertimbangan untuk menentukan kelanjutan kerjasama dengan supplier komputer.

\section{PERANCANGAN SISTEM}

Analisis dan perancangan yang digunakan dalam penelitian ini menggunakan metode Structured Analysis and Structured Design. Alat bantu yang digunakan adalah Statement of Purpose (SOP), Event List, Context Diagram, Data Flow Diagram (DFD). Perancangan database dilakukan dengan menggunakan Entity Relationship Diagram (ERD).

\section{Statement Of Purpose}

Sistem mampu memberikan gambaran mengenai kondisi ormawa yang ada di STMIK STIKOM Indonesia. Kondisi ormawa dilihat dari keaktifan anggota ormawa, kegiatan yang dilakukan ormawa beserta partisipannya, dan kedisiplinan ormawa dalam membuat laporan pertanggungjawaban.

\section{Event List} SIMAWA:
1. Input Tahun Ajaran

2. Pengelolaan Ormawa dan Pembina

2.1. Input ormawa

2.2. Update ormawa

2.3. Input pembina

2.4. Update Pembina

3. Pengelolaan Laporan

3.1. Pengolahan laporan kondisi ormawa

3.2. Pengolahan laporan kegiatan ormawa

3.3. Pengolahan laporan keaktifan ormawa

4. Input Absensi Pertemuan Rutin

5. Input Anggota

6. Pengelolaan Kegiatan

6.1. Input usulan kegiatan

6.2. Approval pembina ormawa

6.3. Approval bidang kemahasiswaan

6.4. Input LPJ

6.5. Approval LPJ

\section{Context Diagram}

Sistem yang dikembangkan diberi nama SIMAWA. Ada tiga macam pengguna yang menggunakan SIMAWA, yaitu ormawa, pembina, dan bidang kemahasiswaan. Pengguna ini direpresentasikan dalam bentuk external entities, di dalam Context Diagram, yang akan berinteraksi dengan SIMAWA. Context Diagram dari SIMAWA dideskripsikan dalam Gambar 1.

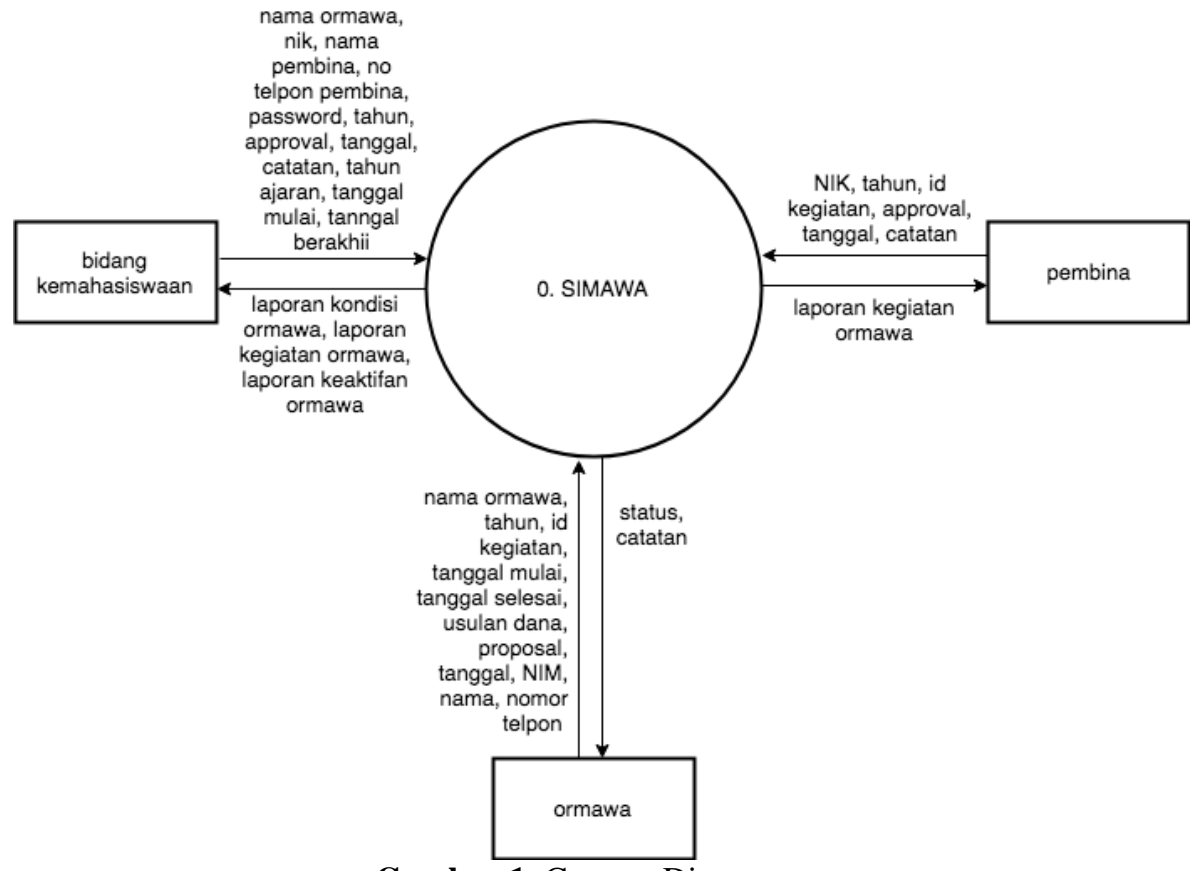

Gambar 1. Context Diagram 


\section{Data Flow Diagram (DFD) Level 0}

Gambaran yang lebih rinci mengenai SIMAWA dideskripsikan dalam Data Flow Diagram (DFD) Level 0, yang disajikan dalam Gambar 2. Ada enam proses yang ada di dalam SIMAWA, yaitu proses input tahun ajaran, proses pengelolaan ormawa dan pembina, proses pengelolaan laporan, proses input absensi pertemuan rutin, proses input anggota ormawa, dan proses pengelolaan kegiatan. Ada enam data storage yang ada di dalam SIMAWA, yaitu tb_pembina, tb_ormawa, tb_absensi, tb_anggota, tb_kegiatan, dan tb_lpj.

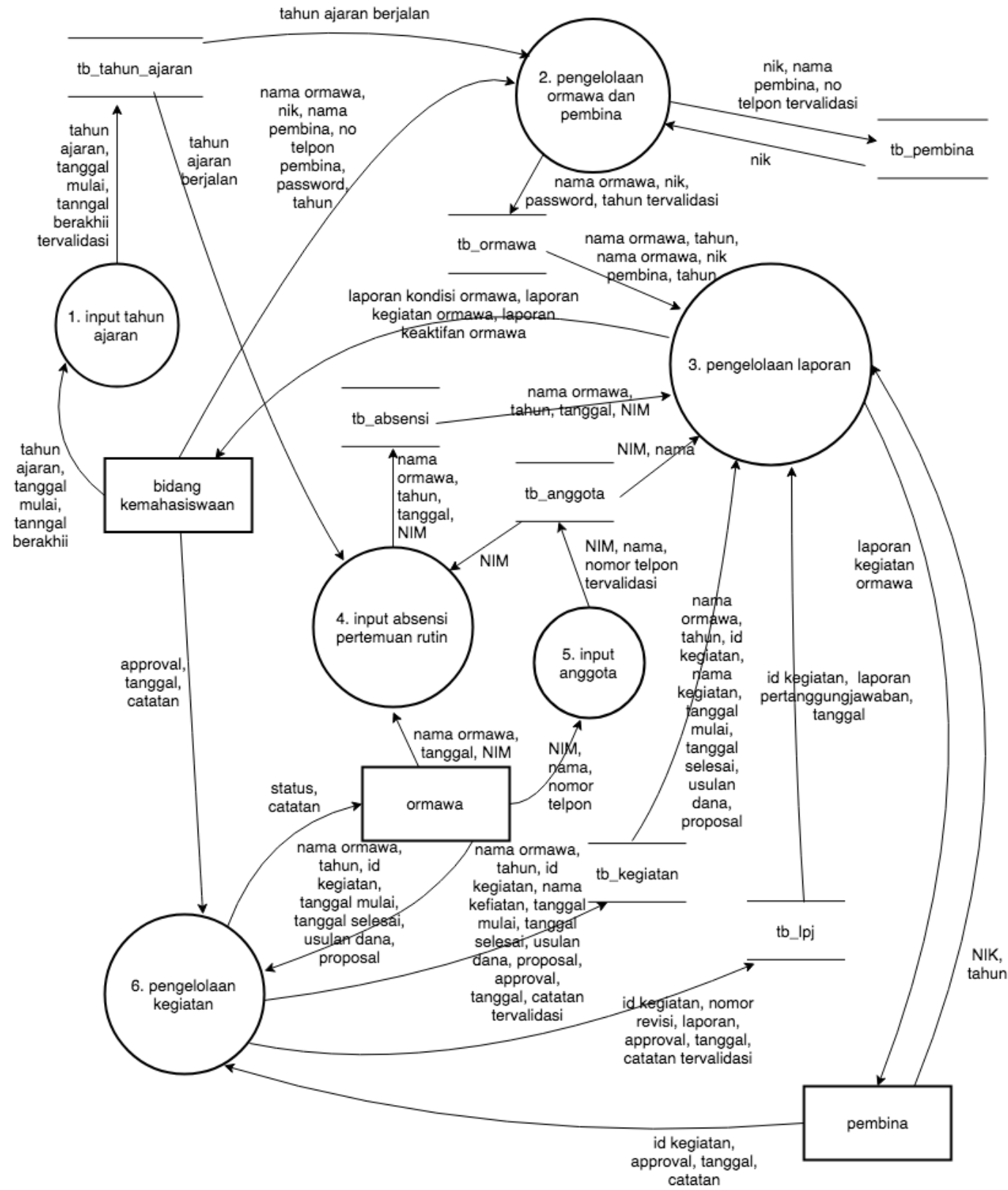

Gambar 2. Data Flow Diagram (DFD) Level 0

\section{Entity Relationship Diagram (ERD)}

Ada tujuh entitas yang terdapat di dalam SIMAWA. Entitas-entitas tersebut antara lain ormawa, tahun ajaran, pembina, kegiatan, LPJ, anggota, dan absensi. Entitas-entitas terebut berserta relasi dan atributnya dinyatakan dalam bentuk Entity Relationship Diagram (ERD), seperti yang dideskripsikan dalan Gambar 3.

\section{Penentuan Kondisi Ormawa Menggunakan SAW}

Penentuan kondisi ormawa dengan menggunakan metode Simple Additive 
Weighting (SAW) melibatkan empat parameter, yaitu keaktifan, jenis acara, jumlah peserta dan waktu penyerahan LPJ.

\section{a. Keaktifan}

Keaktifan yang digunakan dalam parameter ini adalah jumlah kehadiran anggota ormawa dalam pertemuan rutin yang diadakan oleh ormawa. Prasyarat ormawa tersebut aktif adalah jumlah peserta yang hadir dalam pertemuan rutin tersebut minimal 30 orang, dan $75 \%$ kehadiran dari total pertemuan rutin yang diadakan oleh ormawa.

b. Skala Acara

Skala acara yang digunakan dalam parameter ini ada empat kriteria, yaitu skala internasional, nasional, regional dan lokal. c. Jumlah peserta

Pada parameter ini dilihat dari rata-rata jumlah peserta dari kegiatan (poin b) yang diadakan ormawa tersebut. Parameter ini dibagi menjadi lima kriteria, yaitu jumlah peserta lebih dari 800, antara 600 sampai 800, antara 400 sampai 600, antara 200 sampai 400, dan kurang dari 200.

d. Waktu penyerahan LPJ

Lama penyerahan LPJ juga menjadi salah satu parameter dalam perhitungan. Parameter ini dilihat dari waktu rata-rata penyerahan LPJ yang dibagi menjadi empat kriteria, yaitu: lebih dari 3 bulan, 2 sampai 3 bulan, 1 sampai 2 bulan, kurang dari 1 bulan.

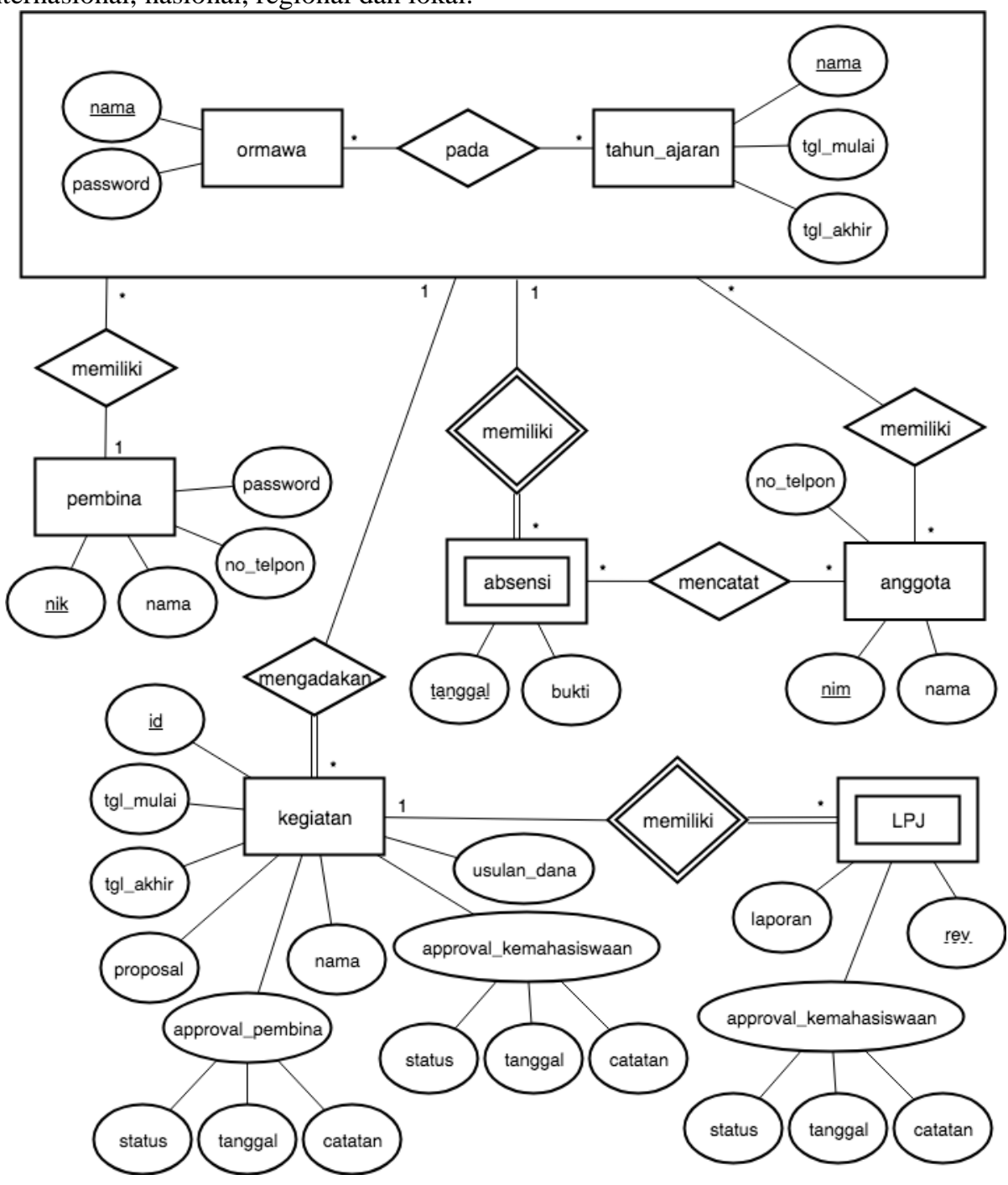

Gambar 3. Entity Relationship Diagram (ERD) 


\section{HASIL DAN PEMBAHASAN}

Berikut ini beberapa tampilan aplikasi yang telah dikembangkan. Form administrasi bagian kemahasiswaan tampak pada gambar 4.1. Pada bagian ini, administrator bagian kemahasiswaan dapat mendaftarkan
ORMAWA yang aktif pada tahun tersebut, mendaftarkan Pembina, melihat data kegiatan yang diajukan oleh masing-masing ORMAWA untuk di setujui, melihat laporan kegiatan ORMAWA, laporan keaktifan ORMAWA dan laporan Kondisi ORMAWA

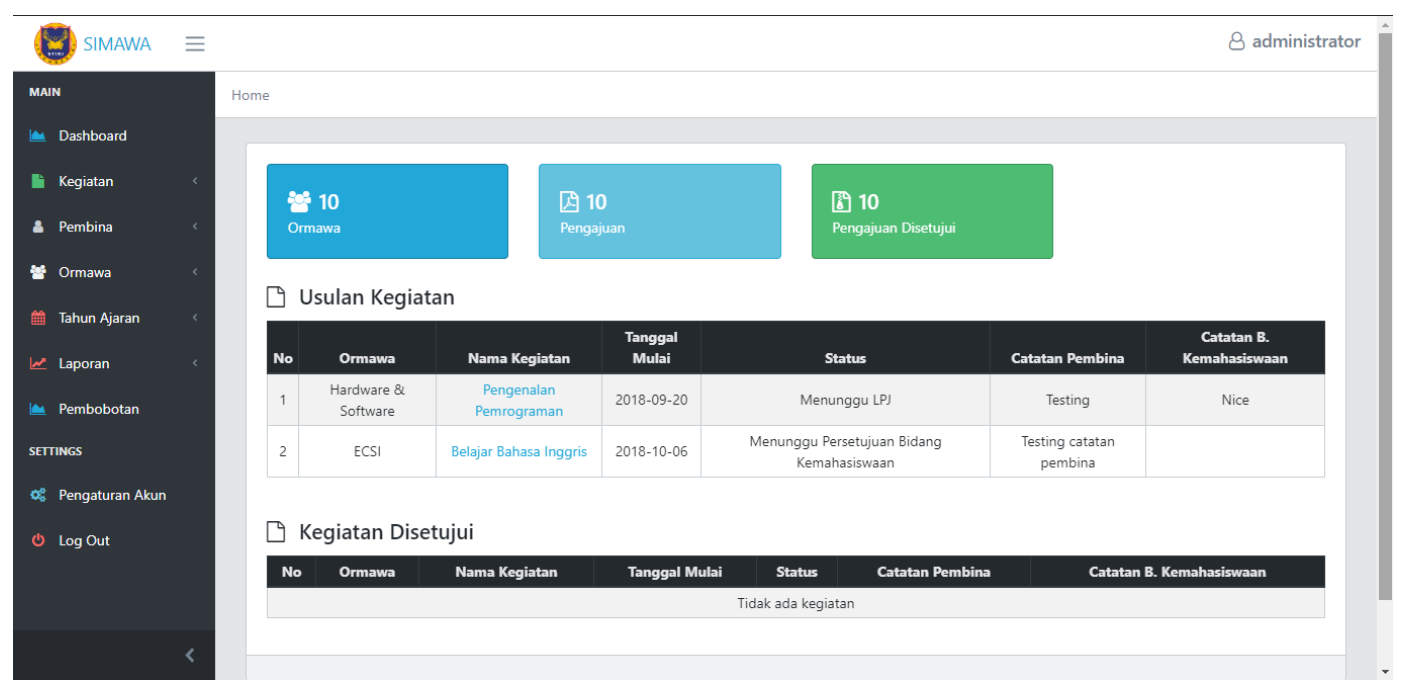

Gambar 4. Halaman administrator bagian kemahasiswaan

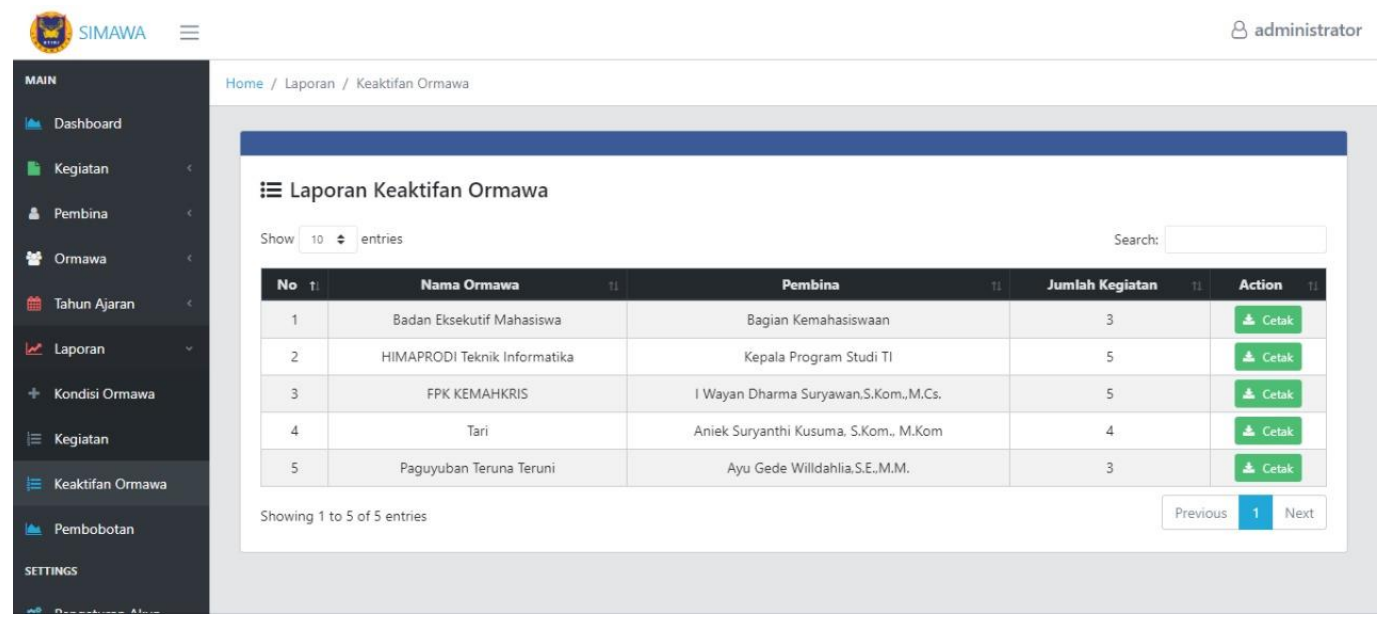

Gambar 5. Halaman laporan keaktifan ORMAWA

Halaman laporan keaktifan ORMAWA tampak pada gambar 5. Pada laporan keaktifan ormawa ini dapat terlihat jumlah kegiatan dari masingmasing ormawa, dan laporan ini dapat di cetak 


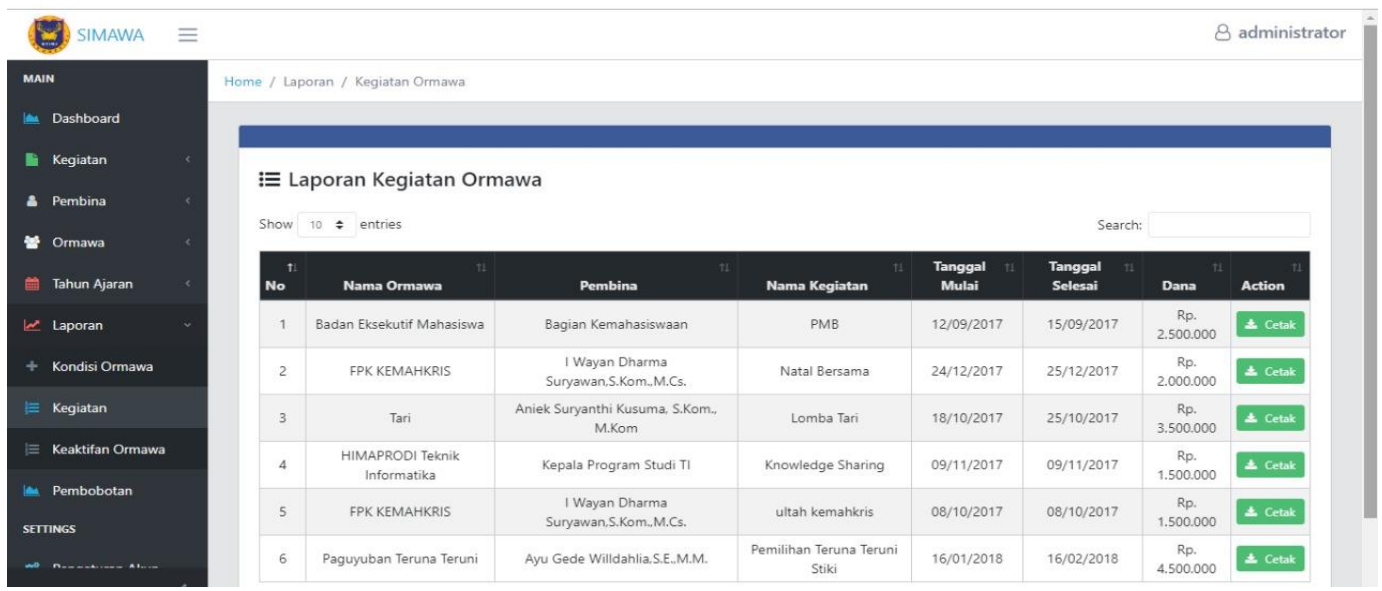

Gambar 6. Halaman Laporan kegiatan ORMAWA

Halaman laporan kegiatan ORMAWA tampak Pada gambar 7, laporan kondisi ORMAWA pada gambar 6. Laporan kegiatan ORMAWA menunjukkan status dari ORMAWA tersebut. ini mencakup tentang nama kegiatan, tanggal Laporan kondisi ORMAWA ini di peroleh dari mulai dan tanggal akhir kegiatan serta proses perhitungan SAW.

pendanaan yang telah di setujui.

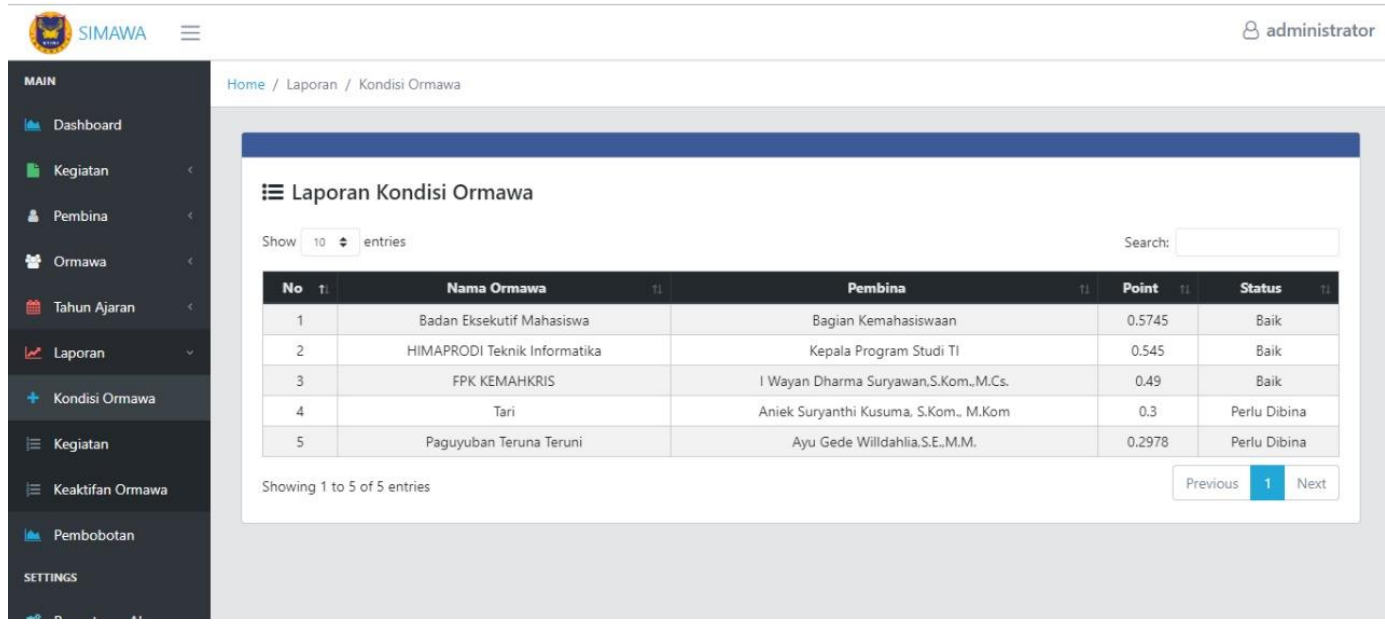

Gambar 7. Laporan Kondisi ORMAWA

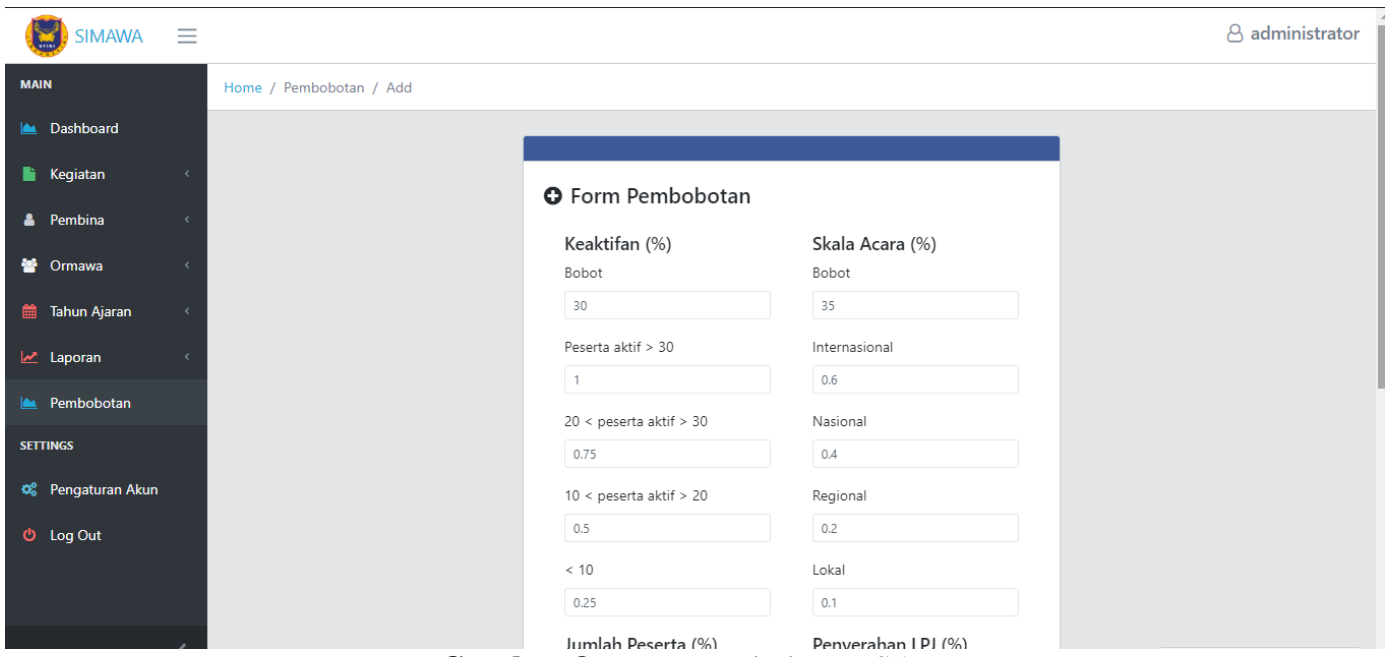

Gambar 8. Form pembobotan SAW 
Pembobotan untuk proses perhitungan SAW tampak pada gambar 8. Pembobotan ini meliputi parameter keaktifan, skala acara, jumlah peserta dan lama penyerahan LPJ

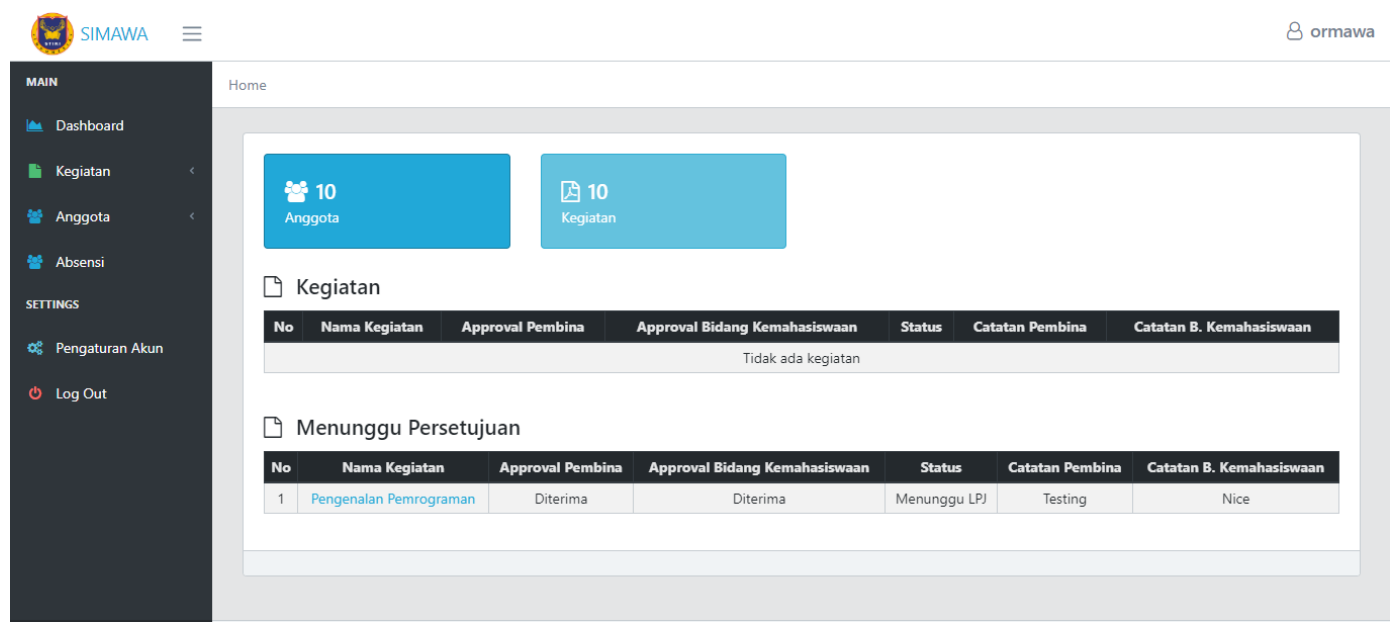

Gambar 9. Halaman dashboard untuk ORMAWA

Halaman dashboard untuk ORMAWA ini meliputi pengajuan kegiatan yang akan diadakan, absensi anggota dan anggota ORMAWA ditunjukan pada gambar 9. Kegiatan yang diajukan oleh ORMAWA ini baru dapat dijalankan setelah mendapatkan persetujuan dari pembimbing dan bidang kemahasiswaan.
Untuk halaman dashboard pembimbing tampak pada gambar 10. Pada dashboard pembimbing, pembimbing dapat melakukan pengecekan kegiatan yang diajukan oleh ORMAWA. Apabila kegiatan tersebut disetujui oleh pembimbing, kemudian kegiatan tersebut akan di verifikasi oleh bidang kemahasiswaan

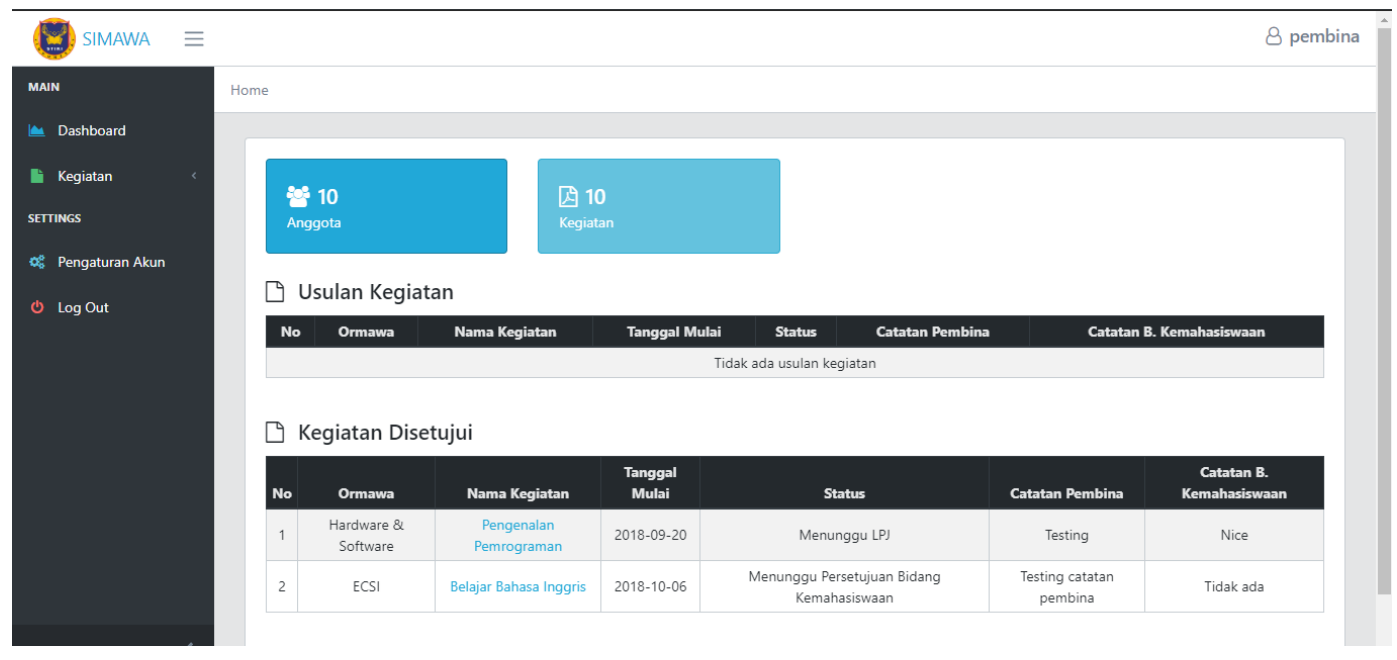

Gambar 10. Dashboard pembimbing

\section{SIMPULAN}

Dari penelitian ini adalah metode SAW tidak dapat digunakan untuk menentukan kondisi ormawa dengan baik. Hal ini disebabkan karena penilaian dilakukan secara relatif terhadap kondisi ormawa yang lain. Penilaian secara relatif ini dapat menghasilkan penilaian yang berbeda terhadap kondisi yang sama. Metode lain yang dapat memberikan penilaian yang lebih baik diperlukan untuk menyelesaikan masalah ini. 
DAFTAR PUSTAKA

Ardiana., D.P. Y., Loekito, L. H., 2018, SISTEM INFORMASI PERAMALAN PERSEDIAAN BARANG MENGGUNAKAN METODE WEIGHTED MOVING AVERAGE, Jurnal Teknologi Informasi dan Komputer (JuTIK), VOL.4 , NO. 1, September 2018, hal 71-79.

Pertiwi, M.C., Sulistiyawan, A., Rahmawati, I., dan Kaltsum, H.U., 2015, HUBUNGAN ORGANISASI DENGAN MAHASISWA DALAM MENCIPTAKAN LEADERSHIP, Prosiding Seminar Nasional dan Call for Papers "Aktualisasi Bimbingan Konseling pada Pendidikan Dasar Menuju Peserta Didik yang Berkarakter" Cetakan Pertama, Surakarta

Pratiwi, S.S., 2017, PENGARUH KEAKTIFAN MAHASISWA DALAM ORGANISASI DAN MOTIVASI BELAJAR TERHADAP PRESTASI BELAJAR MAHASISWA FAKULTAS EKONOMI UNIVERSITAS NEGERI YOGYAKARTA, Jurnal Pendidikan dan
Ekonomi, Volume 6, Nomor 1, Tahun 2017, hal 54-64

Sadewa, I. dan Siahaan, K., 2016, ANALISIS

DAN PERANCANGAN SISTEM

INFORMASI UNIT KEGIATAN

MAHASISWA (UKM) BERBASIS WEB PADA UNIVERSITAS BATANGHARI, Jurnal Manajemen Sistem Informasi Vol 1 No. 2, Desember 2016, hal 135-146

Mulyani, S.M., 2016, RANCANG BANGUN SISTEM INFORMASI SISTEM KREDIT PARTISIPASI AKTIVITAS MAHASISWA (SISKPAM), Jurnal Sistem Informasi (JSI), VOL. 8, NO. 2, Oktober 2016, hal 1069-1079

Gea, A., 2016, FUZZY LOGIC DENGAN METODE MULTI ATRIBUTE DECISION MAKING, Jurnal ISD Vol. 2 No. 2 Juli - Desember 2016, hal 24-31

Harjayanti, J. dan Rozi, A.F., 2016, Sistem Informasi Penilaian Supplier Komputer Menggunakan Metode Fuzzy Multiple Attribute Decision Making Dengan Simple Additive Weighting, Informatics Journal Vol. 1 No. 3, hal 88-95 